\title{
Streptomyces albus G Produces an Antibiotic Complex Identical to Paulomycins A and B
}

\author{
By J. MAJER ${ }^{1 *}$ AND K. F. CHATER ${ }^{2}$ \\ ${ }^{1}$ Northwestern University Medical and Dental Schools, Chicago, Illinois 60611, USA \\ ${ }^{2}$ John Innes Institute, Norwich NR4 7UH, UK
}

(Received 8 December 1986)

\begin{abstract}
An antibiotic complex active against multiply resistant strains of staphylococci and other Grampositive bacteria was isolated from cultures of Streptomyces albus G. Silica gel and Sephadex LH-20 column chromatography gave two congeners with $M_{\mathrm{r}}$ values of 786 and 772 , which differed by one $-\mathrm{CH}_{2}$-group. The two homologues contained an isothiocyanate group, and proved to be identical with paulomycins A and B produced by Streptomyces paulus; the FAB mass spectra, in addition, proved the same two congeners to be present in proceomycin obtained from Streptomyces alboniger.
\end{abstract}

\section{INTRODUCTION}

Although very many independently isolated streptomycetes have been described, mainly in connection with their production of antibiotics, only a few have received repeated attention in the scientific literature for reasons other than antibiotic production. Nevertheless, information about other aspects of an organism (e.g. its ecology, physiology and genetics) may eventually provide a rich background within which to analyse antibiotic production. A notable example is provided by Streptomyces coelicolor A3(2), the subject of extensive genetic analysis for about 20 years before it was found to produce four different antibiotics, three of which have since become the focus of molecular genetic studies (see Hopwood et al., 1986).

In the case of $S$. albus G, discovered by Welsch (1936), some genetic analysis has begun, following the isolation of restrictionless mutants such as J1074 (Chater \& Wilde, 1976, 1980), which facilitate its use as an acceptor of DNA from other sources. Protoplasts of mutants can be efficiently regenerated (Baltz \& Matsushima, 1981), and can be transformed by several plasmid (Kieser et al., 1982; Rhodes et al., 1984; Bailey et al., 1986) and phage (Chater et al., 1982) vectors. The early studies of $S$. albus $\mathrm{G}$, however, were primarily biochemical (reviewed by Welsch, 1962): they concerned its bacteriolytic activities, reflected in its renaming as $S$. griseus subsp. solvifaciens (Pridham \& Tresner, 1974), although adherence to the old name has persisted in the literature. Part of the lytic principle, a DD-carboxypeptidase, has recently been intensively studied (e.g. Joris et al., 1983). The early studies (Welsch, 1941) had shown that the enzymic lytic activities were accompanied by 'material of a lipoid nature specifically bactericidal for Grampositive bacteria'. In the course of genetic studies, we noticed that some mutants of $S$. albus $\mathrm{G}$ were sensitive to a diffusible product of the wild-type cultures. In this study the product was purified and identified, and its activity against other Gram-positive bacteria was determined.

\section{METHODS}

Strains. The type strain of $S$. albus $\mathrm{G}$ was originally obtained from $\mathrm{Dr} \mathrm{R}$. J. Roberts. After treatment with $N$ methyl- $N^{\prime}$-nitro- $N$-nitrosoguanidine (NTG) (Delić et al., 1970), a mutant (J1670) with increased production of the antibiotic was selected and used in this study.

Abbreviation: NTG, $N$-methyl- $N^{\prime}$-nitro- $N$-nitrosoguanidine. 
Sporulation medium and maintenance. Complete medium slants (Hopwood, 1967) were incubated at $28^{\circ} \mathrm{C}$. Slants of the sporulated cultures were stored at $4{ }^{\circ} \mathrm{C}$, or spores were harvested, filtered, pelleted, resuspended in glycerol $(20 \%, \mathrm{v} / \mathrm{v})$ and kept at $-15{ }^{\circ} \mathrm{C}$.

Seed culture and fermentation medium. Seed culture medium was prepared according to Martin et al. (1966) and $100 \mathrm{ml}$ of the medium in a $500 \mathrm{ml}$ conical flask was inoculated with about $10^{8}$ spores. After $48 \mathrm{~h}$ at $28^{\circ} \mathrm{C}$ on a rotary shaker (250 r.p.m.), samples $(15 \mathrm{ml})$ were transferred to conical flasks ( $2 \mathrm{l}$ ) containing $300 \mathrm{ml}$ of fermentation medium (Samoylova, 1980) consisting of $\left(\mathrm{g} \mathrm{l}^{-1}\right)$ : D-glucose (10.0); sodium phytate (Sigma) (10.0); corn steep liquor (0.5); L-asparagine (1.0); $\mathrm{MgSO}_{4} .7 \mathrm{H}_{2} \mathrm{O}(0 \cdot 2) ; \mathrm{K}_{2} \mathrm{CO}_{3}(0 \cdot 16)$. The $\mathrm{pH}$ of the medium was adjusted to $7 \cdot 0-7 \cdot 5$, using dilute sulphuric acid; the glucose $(50 \%, w / v)$ was autoclaved separately and added after autoclaving. Incubation for 4-5 d under the same conditions as the seed cultures yielded $15-30 \mu \mathrm{g}$ of the antibiotics $\mathrm{ml}^{-1}$.

Extraction of the fermentation liquid. The cultures were harvested by centrifugation. The supernatant was acidified with citric acid to $\mathrm{pH} 3.5$ and then exhaustively extracted with chloroform/ethyl acetate $(2: 1, \mathrm{v} / \mathrm{v})$. The filtrate of the combined extracts, after drying over anhydrous sodium sulphate, was evaporated to dryness under reduced pressure.

Column chromatography. First, the crude residue was chromatographed on silica gel (EM Reagents; particle size $0.063-0.20 \mathrm{~mm}$ ) in ethyl acetate; elution with the same solvent removed most of the coloured products. Fractions containing bioactive material eluted at about 1 column volume as detected by bioassays with Staphylococcus aureus RN 1389, and by TLC in chloroform/methanol $(95: 5, \mathrm{v} / \mathrm{v})$, using UV light (e.g. $253.7 \mathrm{~nm})$ and/or an anisaldehyde/sulphuric acid/ethanol mixture $(10: 10: 90$, by vol.) for detection. Fractions with bioactivity were combined, reduced in volume and subjected to column chromatography on Sephadex LH-20 in chloroform/hexane $(1: 1, \mathrm{v} / \mathrm{v})$. At an elution rate of $0.2 \mathrm{ml} \mathrm{cm}^{-1} \mathrm{~min}^{-1}$, the major peaks with activity appeared betwen $4 \cdot 5-5 \mathrm{column}$ volumes. Most of the fractions yielded crystals on partial evaporation at room temperature. Recrystallization from chloroform/heptane gave cotton-like crystalline material which melted at $97 \cdot 5-100{ }^{\circ} \mathrm{C}$.

FAB mass spectrometry. This was kindly carried out by Drs D. Noble, J. Herrmann and W. P. Blackstock of Glaxo, Greenford, Middlesex, UK. A Finnigan-MAT 311A mass spectrometer and Incos Data System M-Scan FAB gun with Xenon gas was used only for positive ions, at approximately $10 \mu \mathrm{A}$ and $10 \mathrm{kV}$ using a glycerolthioglycerol matrix; for both positive and negative ion runs, a VG ZAB-2F with 11-250 Data System Ion Tech gun, Xenon, $10 \mu \mathrm{A}$ at $8 \mathrm{kV}$, and a glycerol-thioglycerol matrix, were used.

\section{RESULTS AND DISCUSSION}

In the course of the genetic studies of the restriction and modification of certain bacteriophages by the SalGI (= SalI : Arrand et al., 1978) system of S. albus G (Chater \& Wilde, 1980), we observed that growth of a restriction- and modification-deficient mutant (J1074) was inhibited by the parent strain. We found that most other streptomycetes were also inhibited $(S$. rimosus NRRL 2234 being a rare exception), as were Staph. aureus and Bacillus cereus, but not Escherichia coli. An unclassified wild-type Streptomyces strain (1193) was chosen as a particularly sensitive indicator strain to aid preliminary purification. Partially purified material (initially termed 'salgiomycin') was obtained which very strongly inhibited growth of strain 1193 and Staph. aureus.

In view of its unusually potent anti-staphylococcal activity, 'salgiomycin' was extensively purified as described in Methods from culture fluids of an over-producing mutant obtained after NTG mutagenesis. Its antimicrobial activity is indicated in Table 1.

The IR spectrum (in chloroform) of 'salgiomycin' displayed bands at 3400, 2920, 2030, 1735, $1730,1690,1640$ and $1580 \mathrm{~cm}^{-1}$, of which the strong absorption band at $2030 \mathrm{~cm}^{-1}$ was indicative of a $\mathrm{X}=\mathrm{Y}=\mathrm{Z}$ cumulene such as $\mathrm{N}=\mathrm{C}=\mathrm{S}$. UV maxima $\left(A_{1 \mathrm{~cm}}^{1 \%}\right)$ in ethanol were at $237 \mathrm{~nm}(154 \cdot 8), 278 \mathrm{~nm}(109 \cdot 6)$ and $324 \mathrm{~nm}(96 \cdot 7)$. The H-NMR spectrum (90 MHz) indicated the presence of several $\mathrm{C}-\mathrm{CH}_{3}$ functions $(\delta 1 \cdot 20-1 \cdot 40)$, one methyl group on an olefinic carbon $(\delta 1.90)$, protons of an acetate methyl group $(\delta 2.07)$, and one methoxy function $(\delta 3.44)$ along with additional resonances upfield and downfield from 5.0 p.p.m. The mass spectrum (electron impact) included fragments of $m / z 514,496,371,315,143,112,111$ and 93 with no evidence of a molecular ion.

For the definitive structural assignment the availability of FAB mass spectrometry proved invaluable. First, evidence of the presence of homologues with $M_{\mathrm{r}}$ values of 786 and 772 , corresponding to molecular formulae $\mathrm{C}_{34} \mathrm{H}_{46} \mathrm{~N}_{2} \mathrm{O}_{17} \mathrm{~S}$ and $\mathrm{C}_{33} \mathrm{H}_{44} \mathrm{~N}_{2} \mathrm{O}_{17} \mathrm{~S}$ respectively, was 
Table 1. Antibacterial spectrum of $S$. albus $G$ antibiotics compared with major antibiotics

\begin{tabular}{|c|c|c|c|c|c|}
\hline \multirow[b]{2}{*}{ Micro-organism } & \multicolumn{5}{|c|}{ MIC $\left(\mu \mathrm{g} \mathrm{ml}^{-1}\right)$ in agar } \\
\hline & $\begin{array}{l}\text { S. albus } \mathrm{G} \\
\text { antibiotics }\end{array}$ & $\begin{array}{l}\text { Chloram- } \\
\text { phenicol }\end{array}$ & $\begin{array}{c}\text { Erythro- } \\
\text { mycin }\end{array}$ & $\begin{array}{l}\text { Tetra- } \\
\text { cycline }\end{array}$ & Monensin \\
\hline Staphylococcus aureus W & $0 \cdot 4$ & $6 \cdot 3$ & 100 & $>100$ & $12 \cdot 5$ \\
\hline Staphylococcus aureus KY 8953 & 0.4 & $3 \cdot 1$ & $>100$ & 100 & $12 \cdot 5$ \\
\hline Staphylococcus aureus R8 & $0 \cdot 4$ & $3 \cdot 1$ & $6 \cdot 3$ & 100 & $12 \cdot 5$ \\
\hline Staphylococcus aureus RN 1389 & $0 \cdot 2$ & $3 \cdot 1$ & 0.2 & $<0.05$ & $12 \cdot 5$ \\
\hline Enterococcus faecalis & 1.6 & $12 \cdot 5$ & 0.1 & 0.2 & 100 \\
\hline Bacillus subtilis & 0.8 & $3 \cdot 1$ & 0.2 & $3 \cdot 1$ & $6 \cdot 3$ \\
\hline Sarcina lutea & $0 \cdot 2$ & 1.6 & $<0.05$ & 0.2 & 25 \\
\hline Proteus vulgaris & $>100$ & 1.6 & $>100$ & $6 \cdot 3$ & $>100$ \\
\hline Escherichia coli & 100 & $6 \cdot 3$ & $>100$ & 0.4 & $>100$ \\
\hline Pseudomonas aeruginosa & 100 & 100 & $>100$ & $6 \cdot 3$ & $>100$ \\
\hline Klebsiella pneumoniae & 100 & $0 \cdot 8$ & $3 \cdot 1$ & 0.2 & $>100$ \\
\hline
\end{tabular}

readily obtained, based on (i) positive quasi-molecular peaks generated in glycerol-thioglycerol and alkali salts

$$
\begin{aligned}
& m / z 795[M+\mathrm{Na}]^{+} ; m / z 903[M+\mathrm{Na}+\text { thioglycerol }]^{+},(\mathrm{R}=\mathrm{H}) \\
& m / z 809[M+\mathrm{Na}]^{+} ; m / z 917[M+\mathrm{Na}+\text { thioglycerol }]^{+},\left(\mathrm{R}=\mathrm{CH}_{3}\right) \\
& m / z 811[M+\mathrm{K}]^{+}(\mathrm{R}=\mathrm{H}) \\
& m / z 825[M+\mathrm{K}]^{+}\left(\mathrm{R}=\mathrm{CH}_{3}\right)
\end{aligned}
$$

and (ii) negative radical ions $m / z 772(\mathrm{R}=\mathrm{H})$ and $m / z 786\left(\mathrm{R}=\mathrm{CH}_{3}\right)$. Subsequent formation of $m / z 754$ and $m / z 768$, and of $m / z 753$ and $m / z 767$ respectively, after the loss of an $\mathrm{H}_{2} \mathrm{O}$ molecule and a proton, further verified the two $M_{\mathrm{r}}$ values. At this point, a close resemblance was apparent between 'salgiomycin' and the paulomycin A and B complex produced by $S$. paulus (Wiley et al., 1984), and the fragmentation patterns allowed the deduction of structural features which could be compared and matched with the independently obtained paulomycin data. These data are presented in Fig. 1. In the positive ion FAB mode mass spectra, the quasimolecular ion (1) gave as prominent fragments $\mathrm{m} / \mathrm{z} 515$ and $\mathrm{m} / \mathrm{z} 497$ assigned to the monoglycoside (2) following the loss of the deoxysugar and a proton back transfer. This pair of peaks establishes the carbon skeleton common to both congeners. The removal of paulic acid $\left[\mathrm{CH}_{3} \mathrm{CH}=\mathrm{C}(\mathrm{NCS}) \mathrm{COOH}\right]$ and a molecule of $\mathrm{H}_{2} \mathrm{O}$ resulted in the formation of fragments $\mathrm{m} / \mathrm{z}$ 372 and $m / z 354$ respectively. The moiety of the esterified dideoxysugar cleaved off without the glycosidic oxygen atom (3) was observed as $\mathrm{m} / z 273$ and $\mathrm{m} / \mathrm{z} 259$ relative to either of the acyl homologues present as part of the pertinent ester group as well as $m / z 241$ and $m / z 227$ (4) after a loss of $\mathrm{CH}_{3} \mathrm{OH}$. Evidence for the latter structural feature comes from the negative ions observed at $m / z 101\left(\mathrm{R}=\mathrm{CH}_{3}\right)$ and $m / z 87(\mathrm{R}=\mathrm{H})$ consistent with the 2-methylbutyryl and isobutyryl carbon chains as the only structural difference between the two components of the complex.

Occurrence of a pyranose ring in the dideoxysugar was also supported by fragments $\mathrm{m} / z 143$ (5) and $m / z 111(6)$ in the electron impact spectrum (Fig. 2).

Finally, the negative ions $m / z 142, m / z 59$ and $m / z 58$ seen in the FAB spectrum complete the structural assignment as being ascribed to $\mathrm{CH}_{3} \mathrm{CH}=\mathrm{C}(\mathrm{NCS}) \mathrm{COO}^{-}, \mathrm{CH}_{3} \mathrm{COO}^{-}$and $\mathrm{NCS}^{-}$ respectively. A sample of proceomycin, an antibiotic complex from $S$. alboniger (kindly provided by $\mathrm{Dr} \mathrm{H}$. Kawaguchi), gave a similar FAB mass spectrum with different proportions of its two components.

These observations show that the two congeners from $S$. albus $\mathrm{G}$ with $M_{\mathrm{I}}$ values of 786 and 772 are identical to those in proceomycin (Tsukiura et al., 1964) and also to those in the antibiotic U-43,120 (Wiley, 1976), subsequently resolved into paulomycin A and B (Wiley et al., 1984). These antibiotics represent a class of antimicrobials that may include senfolomycins $A$ and B (Mitscher et al., 1966). At present, there is a lack of information about the sequence of reactions involved in the assembly of these metabolites, although continued work on paulomycins (Wiley et al., 1986) indicates that they may be of more than academic interest. The 


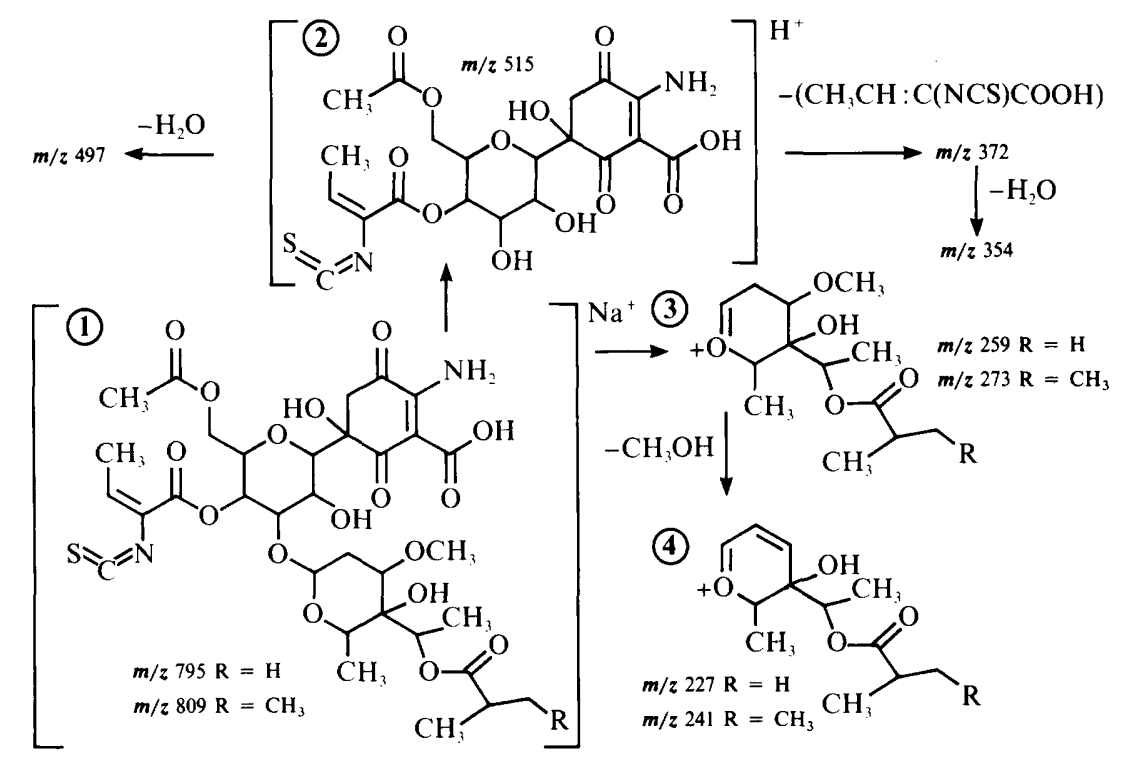

Fig. 1. Positive ion FAB mode spectral degradation of paulomycins A and B.<smiles>COC1CC=[O+]C(C)C1=O</smiles>

Fig. 2. Fragments $m / z 143(5)$ and $m / z 111(6)$ obtained in electron impact mass spectrum.

finding that a representative of this class is produced by $S$. albus $\mathrm{G}$ opens up the possibility of a genetic approach to the study of the biosynthetic pathway and its regulation. This could exploit the large collection of single and multiple auxotrophs in our collection of $S$. albus $G$ derivatives (Chater \& Wilde, 1980 and unpublished), among which two isoleucine-valine auxotrophs (including the parent of J1074) and a guanine auxotroph are non-producers (K. F. Chater, unpublished). It is pertinent in this context to note that $S$. albus $\mathrm{G}$ strain $\mathrm{J} 1074$ is one of the few streptomycetes which have been successfully transformed with large pieces of Streptomyces DNA cloned in $E$. coli using bifunctional cosmid vectors (Rhodes et al., 1984), and that the only documented case in which expression of the pBR322 tet gene was usable for vector selection in a streptomycete also used this strain (Chater et al., 1982).

We thank Professor D. A. Hopwood for providing J. M. with the opportunity to work at the John Innes Institute and Drs D. Noble, J. Herrmann and W. P. Blackstock, Glaxo, Greenford, Middlesex for carrying out FAB mass spectrometry. Thanks are also due to Dr H. Kawaguchi of the Bristol-Banyu Research Institute, Tokyo, for a sample of proceomycin, Dr P. F. Wiley for antibiotic U-43,120, Dr J. B. McAlpine for critical reading of the manuscript and the Upjohn Company Infectious Diseases Research Office (Mr R. L. Keene) for specimens of paulomycin A and B. This work was funded in part by the Office of Research and Sponsored Projects of the Northwestern University. 


\section{REFERENCES}

Arrand, J. R., Myers, P. A. \& Roberts, R. J. (1978). A new restriction endonuclease from Streptomyces albus G. Journal of Molecular Biology 118, 127-135.

Bailey, C. R., Bruton, C. J., Butler, M. J., Chater, K. F., Harris, J. E. \& Hopwood, D. A. (1986). Properties of in vitro recombinant derivatives of pJV1, a multicopy plasmid from Streptomyces phaeochromogenes. Journal of General Microbiology 132, 2071-2078.

Baltz, R. H. \& Matsushima, P. (1981). Protoplast fusion in Streptomyces: conditions for efficient genetic recombination and cell regeneration. Journal of General Microbiology 127, 137-146.

ChateR, K. F. \& WiLDE, L. C. (1976). Restriction of a bacteriophage of Streptomyces albus G involving endonuclease Sall. Journal of Bacteriology 128, 644650.

ChATER, K. F. \& Wilde, L. C. (1980). Streptomyces albus $\mathrm{G}$ mutants defective in the SalGI restrictionmodification system. Journal of General Microbiology 116, 323-339.

Chater, K. F., Bruton, C. J., King, A. A. \& Suarez, J. E. (1982). The expression of Streptomyces and Escherichia coli drug resistance determinants cloned into the Streptomyces phage $\Phi \mathrm{C} 31$. Gene 19, 21-32.

Delić, V., Hopwood, D. A. \& Friend, E. J. (1970). Mutagenesis by $N$-methyl- $N^{\prime}$-nitro- $N$-nitrosoguanidine (NTG) in Streptomyces coelicolor. Mutation Research 9, 167-182.

HopwooD, D. A. (1967). Genetic analysis and genome structure in Streptomyces coelicolor. Bacteriological Reviews 32, 373-403.

Hopwood, D. A., Bibb, M. J., Chater, K. F., Janssen, G. R., Malpartida, F. \& SMith, C. P. (1986). Regulation of gene expression in antibiotic-producing Streptomyces. Symposia of the Society for General Microbiology 39, 251-276.

Joris, B., Van Beevmen, J., Casagrande, F., GerDAY, C., Frère, J.-M. \& GHUYSEN, J.-M. (1983). The complete amino acid sequence of the $\mathrm{Zn}^{++}$-containing D-alanyl-D-alanine-cleaving carboxypeptidase of Streptomyces albus G. European Journal of Biochemistry 130, 53-69.

Kieser, T., Hopwood, D. A., Wright, H. M. \& ThOMPson, C. J. (1982). pIJ101, a multicopy broad host-range Streptomyces plasmid: functional analysis and development of DNA cloning vectors. Molecular and General Genetics 185, 223-238.
Martin, J. R., Perun, T. J. \& Girolami, R. L. (1966). Studies on the biosynthesis of the erythromycins. 1 . Isolation and structure of an intermediate glycoside,

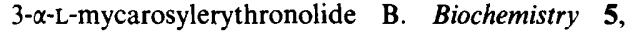
2852-2856.

Mitscher, L. A., McCrae, W., DeVoe, S. E., Shay, A. J., HausmanN, W. K. \& Bohonos, N. (1966). Senfolomycin A and B, new antibiotics. Antimicrobial Agents and Chemotherapy 1965, 828-831.

Pridham, T. G. \& Tresner, H. D. (1974). Streptomycetaceae. In Bergey's Manual of Determinative Bacteriology, 8th edn, pp. 747-845. Edited by R. E. Buchanan \& N. E. Gibbons. Baltimore: Williams \& Wilkins.

Rhodes, P. M., Hunter, I. S., Friend, E. J. \& WARREN, M. (1984). Recombinant DNA methods for the oxytetracycline producer Streptomyces rimosus. Biochemical Society Transactions 12, 586-587.

Samoylova, T. S. (1980). Microbiological degradation of inositol phosphates. Doklady Vsesoyuznoy Akademii Selskochozaystvennych Nauk Imenyi Lenina 9, 1719 (in Russian).

Tsukiura, H., OKanishi, N., Koshiyama, H., OHmori, T., MiYaKi, T. \& Kawaguchi, H. (1964). Proceomycin, a new antibiotic. Journal of Antibiotics 17, 223 229.

WelsCh, M. (1936). Propriétés bactériolytiques du Streptothrix et sporulation. Comptes rendus du Société biologique 123, 1013-1016.

WELSCH, M. (1941). Bactericidal substances from sterile culture-media and bacterial cultures with special reference to the bacteriolytic properties of actinomycetes. Journal of Bacteriology 42, 801-814.

WELSCH, M. (1962). Bacteriolytic enzymes from streptomycetes. A review. Journal of General Physiology 45, 115-124.

WILEY, P. F. (1976). A new antibiotic, U-43, 120 (NSC163500). Journal of Antibiotics 29, 587-589.

Wiley, P. F., MizsaK, S. A., BaczynskyJ, L. \& ARgoudelis, A. D. (1984). The structure of paulomycin. Journal of Antibiotics 37, 1273-1275.

Wiley, P. F., Mizsak, S. A., Baczynskyj, L., Argoudelis, A. D., Duchamp, D. J. \& Watt, W. (1986). The structure and chemistry of paulomycin. Journal of Organic Chemistry 51, 2493-2499. 